\title{
The status of Indigenous Australians
}

$\mathrm{T}$ HERE ARE A number of avenues through which the 'place' of Indigenous people in Australia can be approached. One fundamental arena of struggle has been over land rights. The approach to rights taken here, however, starts from an account of suffering and sets out to trace the political roots of that suffering. One of the clearest forms of suffering to mark Aboriginal lives in Australia is entrenched and widespread ill-health. Thus, across the Indigenous community, the story is one of premature death, often from diseases associated with poverty, poor environmental health and mental distress, a high death rate for infants and small children, and appallingly high rates of suicide, violence and substance abuse.

As will become clear, patterns of ill-health lock into the struggles around land rights. At a concrete level, however, almost all Indigenous Australians, including those who live beyond the immediate scope of land rights, are affected by high levels of disease. Questions of Aboriginal health often have a curious status. The linkage between Aboriginal ill-health and what could be called, rather neutrally, Indigenous disadvantage in Australia is taken for granted - for example, in the use of mortality rates as a standard statistical measure indicative of broader life conditions. However, in this case the causal linkage between specifically political orders and patterns of disease can seem frayed. There are no powerful political forces fighting improvements in health, as there are for progress on land rights. On the contrary, since the 1960s at least, the Australian Government has, as well as other relevant bodies, been expressing increasing concern, investigating and writing reports and budgeting monies in response to Aboriginal ill-health. The challenge then is to make clear the political dimensions of Indigenous ill-health, not just in the past but in contemporary political life - in effect, to clarify the linkage between health and land rights, while recognising their specificities.

Unlike the other case studies, this one examines a situation of persistent systemic infliction of abuse in the context of a wealthy, liberal democratic state 
which enjoys extensive rule of law and which has a reasonably active record of human rights promotion internationally. Meanwhile, in the conditions in which most Aboriginal Australians live their lives, their 'life chances' - understood as access to health, education and employment - are comparable to those of people in a poor Third World economy; for many Aborigines participation in decision making concerning basic control over their own lives and environment has, at least until the mid-1980s, been at a lower level than that routinely available in many highly authoritarian societies, and the extent of the violence both generated within and endured by the Aboriginal community, including at the hands of the police, is comparable to that of countries with little tradition of the rule of law. Moreover, these conditions are not such as can be put securely into the 'otherworld' of the distant past and attributed to the excesses of a frontier mentality.

The extent of on-going Indigenous suffering can be approached as an incomplete application of liberal values, practices and processes - a failure in this problematic instance to apply the procedures and values more or less in play in most other zones of contemporary Australian society. But it can also be approached as a product of those procedures, practices and values. These two approaches are in complex tension with each other. The way we weigh patterns of politically generated suffering, so that generations of Aboriginal ill-health and early death, often from violence, seem so extraordinarily less grave than the killings in Tiananmen Square, is itself in part informed by a Lockean language of self-possessed individuality, political community and injury. That large-scale human rights abuse is not something that happens only 'somewhere else' perpetrated by other peoples or at other times, or in societies with authoritarian political structures or poverty-stricken economies, underdeveloped legal systems or immature 'civil societies' - is a simple point that can nevertheless prove extraordinarily difficult to grasp in practice.

This case study thus considers some of the limitations of those dominant understandings of rights that mark both international rights promotion and the constitution of the liberal state. How we understand and pursue principles of participation, dialogue and negotiation is a particular focus of this chapter. This is a matter at the core of the approach to rights pursued here as participation, dialogue and negotiation are also, more broadly, fundamental to liberal norms of state legitimacy. Exploring the question of what participation has meant and might mean for Indigenous Australians in the context of Australian political community underlines the narrow parameters within which participation has been envisaged and in practice offered to Indigenous peoples. More positively, such a discussion is also a reminder of the dynamic and evolving nature of participation as a principle - a dynamism that will need to be engaged if the pattern of systemically imposed injury borne by this sector of the Australian population is to be addressed. 
Approaching health as a matter of human rights can be contentious - certainly more contentious than the subjects of the other two case studies, which can be easily bundled under the category of civil and political rights abuse. There can be some polite disbelief as to the gravity of ill-health as properly an issue of rights, despite the international focus on Indigenous rights, despite declared rights to 'the highest attainable standard of physical and mental health' referred to in the UN Covenant on Economic, Social and Cultural Rights, and despite many states' legal or political commitments to their citizens' health entitlements. Or, worse, the matter can appear simply uninteresting. In contrast to the internationally broadcast acts of violence in Tiananmen or the relentless war of attrition in East Timor, the ill-health characteristic of indigenous communities has not been a focus of searching international attention. While accepting the natural impact of dramatic and tragic events, it is worth noting that the deformation of Indigenous peoples' lives and their appalling levels of disadvantage, expressed directly in their high rates of premature death, goes comparatively unnoticed in international rights talk.

Health is an issue that falls self-evidently into the 'social and economic', or 'second-generation', component of the standard, if misleading, international divisions of human rights. It has been argued in earlier chapters that rights are always essentially political in that they are concerned with the production of the social, economic, legal, cultural and political categories and mechanisms - the structures of power, broadly understood - that shape people's participation within the communities that they inhabit and constitute. In this sense the right to an attainable health standard is not solely a matter of the distribution of material goods and services, although improved distribution should generally result from the recognition of such a right and, crucially, contribute to people's capacity to exercise it. More fundamentally, the right to (attainable) health is a question of the production of the capabilities and the practices by which over generations people participate in, and constitute, community. The persistent lack of adequate nutrition, for example, excludes people from effective political and social participation and, within the broader context of a well nourished environment, indicates their marginalisation in the first place. Health entitlements are important not only because health is important but because collective patterns of ill-health can both demonstrate political marginalisation in operation and themselves act to marginalise people. To look at Aboriginal health, then, is to question certain constructions of political community in Australia which have arguably worked to systemically marginalise and deform constituencies within the Australian population.

Aboriginal disadvantage is sufficiently acute to be noted by various international and domestic Australian registers as an abuse of rights. Bodies such as Amnesty International, the World Council of Churches and the US State Department regularly comment on patterns of systemically imposed discrimination. 
Most notably, UN committees and treaty monitoring bodies have been increasingly expressing their concern with aspects of Indigenous life conditions, with the UN Committee on the Elimination of Racial Discrimination (land rights and sentencing regimes), the UN Human Rights Commission and the Committee Against Torture (sentencing regimes and incarceration practices) registering disapproval during 2000. The Australian Government's response (as of 2001) has been to downgrade its cooperation with UN human rights bodies.

Within Australia, Indigenous disadvantage is sometimes assumed to be largely self-inflicted or, perhaps more commonly, rooted in a cultural context that is profoundly out of step with modern life or in an ancient history of dispossession. Thus, in 1999, the federal government rejected the proposal that an official apology be made to the Aboriginal Australians as part of a process of reconciliation and instead offered an expression of regret that they had 'suffered injustices under the practices of past generations' (Prime Minister Howard, Australian Parliament, 26 August). But, as will become clear, these perceptions are deeply misleading.

At the same time, however, various dimensions of Indigenous disenfranchisement are being documented with increasing urgency, power and detail - by the Royal Commission into Aboriginal Deaths in Custody (RCIADIC), the Aboriginal and Torres Strait Islander Social Justice Commission, the Human Rights Commission, among many other official, scholarly and personal accounts of life conditions. Landmark high court judgments recognised the existence of Indigenous land rights (Mabo, 1992) and upheld the principle of negotiation to manage joint rights to land held by Indigenous and nonindigenous parties (Wik, 1996). In 1991, the Labour Government set up the Council for Aboriginal Reconciliation to explore and promote reconciliation between Aboriginal and settler societies. The Council's report in 2000 was, however, rejected by the Liberal-National Government. As noted above, the government (in particular the prime minister) also declined to apologise to Aboriginal people 'for the errors and misdeeds of earlier generations' - an Indigenous demand and recommendation emerging from both the Human Rights Commission's report (Bringing Them Home) and the Council for Aboriginal Reconciliation (Howard, Parliament, 26 August 1999). (However, all state, i.e. provincial, governments as well as many leading political and social bodies and, through marches and displays, large numbers of people, have apologised.)

The reports, the numerous court cases brought by Aboriginal people on contentious political and social matters (such as land rights), the controversy generated over the prime minister's refusal to 'say sorry' and over continuing deaths of Aboriginal people in custody have generated an unprecedented level of attention to the realities of Aboriginal Australia. As the historian Rosalind Kidd noted: 'Only recently has the irrefutable evidence that Australia was not peacefully settled impacted on our consciousness', although the violent realities of settle- 
ment were 'common knowledge in the nineteenth century' (2000: 4). This tentative and fraught awakening, in conjunction with the Mabo and Wik decisions, represents a breakthrough in political life in Australia the dimensions and significance of which cannot yet be judged. In terms of concrete gains for the lives of Indigenous people, however, there has been little progress. The number of Indigenous deaths in custody has risen since delivery in 1991 of the report investigating the jail and prison death rate over the preceding decade. Incarceration rates of Aboriginal people (approximately twenty-one times that of nonAboriginal people) have likewise increased. Despite real progress on land rights, land reserved for Aboriginal use continues to be alienated for the benefit of mining and other interests. And health standards remain abysmal.

There is a further problem with understanding disease as an abuse of rights in cases such as this. As the Aboriginal activist Noel Pearson has commented in relation to substance abuse:

[T] he symptom theory [that addiction is a symptom of underlying political problems] absolves people from their personal responsibility to confront and deal with addiction. Worse, it leaves communities to think that nothing can be done to confront substance abuse because its purported causes: dispossession, racism, trauma and poverty, are beyond reach of social resolution at present. (2000: 10-11)

This raises the question, one which sears through many rights issues, not only those domains classified as economic and social, of how we understand 'will', 'autonomy' and 'responsibility'. I cannot answer this question, but only respond in a limited and interim way to Noel Pearson's warning. Various kinds of factors are relevant to health, including genetic susceptibilities not even touched on here. These factors interact but do not necessarily overrule each other. Local Indigenous community efforts to deal with particular health problems have been significant and are a fundamental practical dimension of the approach supported here. A sense of individual or local responsibility can be a powerful and empowering imperative - we have and we need different modes of address when grappling with complex social, personal and political problems. But marked, collective, and longstanding patterns of disease among a particular group in an otherwise comparatively healthy society call for analyses and responses that go beyond a consideration of individual responsibility. Indeed, lack of individual responsibility has been for some time a ground on which white Australians have dismissed the problems of Aboriginal society. It is surely essential for Aborigines to consider their individual and collective responsibility for health choices. But it is equally essential for settler Australians to consider our own collective, intergenerational responsibilities for the conditions of Aboriginal lives, and to reflect also on the kind of political engagements we wish to carry forward. 
The chapter briefly establishes the current conditions of Aboriginal health in Australia. While discussing the broad causes of ill-health, it examines the construction of the 'Aboriginal problem', an apparent conundrum which has dominated government and popular approaches to Aboriginal welfare and according to which the 'chronic destitution' (Kidd, 1997: xix) of much of the Aboriginal population is seen as a mysterious state of affairs that is less an ordinary consequence of actions taken regarding Indigenous people than a reflection of Aboriginality itself. The discussion looks briefly at federal government measures since the late 1970s to improve Indigenous health and considers why these measures have in large part failed. It explores the continuing impact of what the Australian anthropologist W. E. H. Stanner in 1968 called the 'great Australian silence' - a consistent 'overlooking' of Indigenous people that could be understood as the inability to recognise them as participants in the construction of political community.

The 'silence' concerning Indigenous people is not peculiar to Australia. It has arguably been characteristic of the response to Indigenous people generated by colonialism and the globalisation of the nation state in the modern era. In this sense, the circumstances of Aboriginal people are not only an Australian domestic phenomenon but are interwoven with the history and constitution of the international state system. It is not surprising that Aboriginal efforts to overturn discrimination at home have increasingly drawn on Indigenous struggles elsewhere and on available international mechanisms and institutions, particularly UN mechanisms. The signing of the Convention on the Elimination of Racial Discrimination (CERD) and its enactment in Australian domestic legislation in 1975 in the form of the Racial Discrimination Act, the 1967 referendum on the status of Aborigines and the Mabo decision on native title (touched on later in the chapter) are notable examples of the contemporary interplay of domestic and international norms and pressures upon which Aboriginal people have been able to call. The UN plays an important role here, offering different forms of scrutiny, different coalitions, different frameworks of comparison from those generated domestically. The UN has been part of the long negotiation between Indigenous and non-indigenous peoples over questions of selfdetermination - quite naturally, as the questions posed by the life conditions of Indigenous peoples are also international questions.

The Australian Government has at times played an active role promoting human rights in the international arena. Indeed, in the late 1940s and the 1950s Australia was one of the founding parties arguing for and engaged in the drafting of the Universal Declaration and key elements of the UN rights architecture. It was at this time that, for example, the forced removal of mixedrace children from Indigenous parents, by authorities throughout the country, was at its height. This draws discussion back to the question not of hypocrisy but of how we grasp the principles and institutions that we hold aloft. It 
is a reminder of the need for conversations across societies on patterns of suffering.

This chapter addresses a pattern of ill-health; it is not about Aboriginal people per se, in their diversity and survival; it is about a history of profoundly injurious political interactions. Aboriginal lives are not themselves reducible to these interactions. Nor is it suggesting that patterns of ill-health are only a political matter - whatever may be the underlying causes of disease and dysfunctional lives, once engaged they have their own physiological, psychological and social dynamics.

\section{Aboriginal health in Australia - current conditions}

According to the most recent (1996) census data, the Aboriginal and Torres Strait Islander population accounts for approximately 2.1 per cent of the total Australian population. Indigenous people are distributed relatively evenly throughout remote, rural, small town and city environments although most live outside cities and major towns. The Aboriginal population is younger overall than the national population. This is because birth rates are higher but also because life expectancy for Aboriginal people at birth is twenty years lower than among non-indigenous people, meaning an average life expectancy of 56.9 years for men and 61.7 for women. 'As at 1993, Aboriginal and Torres Strait Islander life expectancy was lower than those for most countries of the world with the exception of some central African countries and India. There has been little improvement in the last 10 years' (AIHWJ, 1997: 9). Moreover, the gap between Australian Indigenous and settler health indices has now significantly outstripped those Indicated by comparable health statistics for New Zealand, Canadian and United States native and settler populations.

Aboriginal infant mortality was for a long time the leading, and perhaps the only, issue in Aboriginal health to capture the attention of the general public. It first became an issue of national concern in the 1960s, when researchers recorded rates among Northern Territory Aborigines of almost twenty times that for settler Australians. By the mid-1980s, infant mortality rates had dropped to approximately four times that for other Australians. A decade later, Aboriginal infants are more than twice as likely as other Australian babies to die at the time of birth and three times more likely to die in early childhood, generally from diseases that have all-but virtually disappeared from white mortality statistics. Many commentators do not expect further improvements using current methods of prenatal and natal health care, for reasons that are discussed later.

Infant mortality, however, is not the area of most marked difference between Indigenous and settler death rates. It is rather the "exceptionally high 
death rates' for young adults and the middle-aged, which are 'up to ten times those of other Australians ... [and] largely account for the very low expectation of life experienced by Aborigines throughout the country. It is this indicator, more than any other, which clearly summarises the extent of Aboriginal health disadvantages' (Thompson, 1991: 239). Moreover, the gap in mortality rates is not being progressively whittled away, as the broader history of health and health services in Australia might lead us to expect. According to the data available, in some regions death rates for Indigenous people between 20 and 40 years of age have increased, with 1990s' rates in some areas being almost 1.5 times those estimated for 1955 to 1964. In some respects, Aboriginal health is worsening (e.g. Hunter, 1999).

The direct causes of death are as notable as the gulf between the average life expectancies of Indigenous and other Australians. The leading causes of death, as of Indigenous ill-health, are the so-called 'life-style' diseases. This stands in sharp contrast to the patterns of mortality and morbidity that characterise the 'Third World' countries - India, Central Africa - with which Aboriginal life expectancy is, as above, commonly compared (Hunter, 1993: 270). Diseases of the circulatory system (heart attacks and strokes) are the most common causes of death. These lead the mortality figures in the settler community also, but there they predominate among the older age groups. A New South Wales study indicated that between the notably young ages of 25 and 44, the relative risk for Aboriginals of ischaemic heart disease was approximately forty times greater than that faced by the total state population (Reid and Trompf, 1991: 330-1). Death by injury, violence and poisoning (road accidents, murder, suicide and substance abuse) is the second leading cause of death. Diseases of the respiratory system (asthma, emphysema and pneumonia), cancer, and nutritional and metabolic disorders (diabetes) are in rank order the next most common factors in morbidity. For Indigenous children, infectious and parasitic diseases - regarded as entirely preventable - are the leading causes of death. Primary causes of death are consistently related to poor diet and social conditions; they affect a higher proportion of the Aboriginal than the non-Aboriginal population, and many Indigenous people suffer while young from diseases that, in the general community, are associated with old age.

Mortality can be seen within the context of patterns of ill-health. Malnutrition remains endemic. Communicable diseases (respiratory tract and middle-ear infections, diarrhoea, trachoma, hepatitis B, tuberculosis and, to a much lesser extent but still present, leprosy) continue to be important factors in Aboriginal ill-health, although they are no longer a primary cause of death for adults. Substance abuse, particularly alcoholism and petrol sniffing, are major contributors to ill-health and provide the context of much death by violence and 
injury. What is notable here is the incidence of conditions that are both a consequence and (like malnutrition) a cause of poverty, the associated prevalence of diseases resulting from poor environmental health, and the rates of death and injury from violence and substance abuse.

The immediate and uncontentious explanations of these patterns are a combination of endemic poverty and, in many outback communities, the simple lack of public services, such as sewage disposal, functional sanitation facilities and water, routinely made available throughout the broader Australian population by local and state governments. Personal and communal poverty, widespread throughout the urban and rural Aboriginal communities, are tied to high unemployment rates and low levels of education. The 1996 census records an unemployment rate of 23 per cent for Indigenous people (compared to 9 per cent for the general population), but if 'work for dole' schemes are included, Aboriginal unemployment stands at 34 per cent. As a result '[a]lmost four in ten Indigenous households were estimated to have either insufficient income to meet basic needs (even before taking housing into account) or not enough income to afford adequate housing' (Australian Bureau of Statistics, 1997: 3). The incidence of mental illness and of intracommunal violence is high. Alcoholism has become entrenched. Removal from traditional sources of food, lack both of nutritional knowledge and of cultural patterns regarding nonindigenous food sources plus the high cost of and poor access to fresh food in outback areas also contribute to poor diet, leading to malnutrition, high blood pressure, diabetes and heart disease. According to the 2000 House of Representatives Standing Committee report, anaemia in children and malnutrition are becoming more common (HRSC, 2000: 82).

Substandard conditions are among the most salient features of rural Aboriginals' lives. 'Nothing ever quite conveys the shock of coming face to face with the living conditions in some of these [rural Aboriginal] communities, the fact that we're still in Australia and not, as [then Senator] Richardson is to say later, some war-ravaged African nation' (Tingle, 1994: 3). Aboriginal living conditions 'are generally characterised by overcrowding, inadequate water and washing facilities, poor sanitation and sewage disposal, limited food storage and sub-optimal food preparation facilities' (Thompson, 1989:187). In 1996-97, 12,000 Indigenous Australians were estimated to be homeless. A visiting Parliamentary Sub-Committee on Human Rights described the living conditions of some Northern Territory communities as 'appalling' and awash in 'an ocean of sewage' in the wet season (Age, 1994: 2). A 1992 survey by the Aboriginal and Torres Strait Islander Commission (ATSIC) found that, of the 838 rural communities and homelands surveyed, water in 306 was unfit for human consumption, affecting 14,510 people, while over 30,000 people had been affected by water restrictions over the past year, mostly due to equipment breakdown. 'About four per cent of the 80,080 Indigenous people covered in the survey had 
no sewage disposal system and nearly eleven per cent had no electricity supply' (ABS, 1997: 18).

Such conditions fundamentally affect every dimension of health care and well-being. They are not only the direct cause of much illness but undermine the provision of infrastructure for more complex health interventions. So, for example, although Aborigines in north Queensland (where a significant number of rural Aboriginal communities are located) make up 45-50 per cent of patients treated in kidney units, taking dialysis machines to Aboriginal communities which lack clean water, sanitation and effective sewage is of debatable value. '[T]he built and physical environments both reflect and exacerbate the poverty and ill-health of Aboriginal communities. They promote a cycle of discrimination, neglect and sickness' (Reid and Trompf, 1991: xvii). A decade later, the need for improved housing and infrastructure is still registered as pressing (e.g. HRSC, 2000).

What are the reasons for this - in the context of present-day Australia - is a truly extraordinary picture: extraordinary in the extent of ill-health and degraded environmental health, in the contrast with non-indigenous Australian health standards, and in the fact that this situation has persisted despite apparently repeated efforts to address it? This chapter discusses a number of answers to this question. But the place to start is the history of the relentless dispossession of Indigenous people, from their land, their traditional social structures, their economy and their place - a place for which they could be makers of and participants in political community. It is a history that the Australian High Court described as 'a legacy of unutterable shame' for contemporary Australia (RCIADIC, 1991, Vol. 2: 3). As Neil Thompson, a prolific commentator on black mortality, has noted:

Not only is the currently markedly lower health status of Aborigines deeply rooted in their substantial social inequality, but many aspects of Aboriginal health also demand a clear understanding of the cultural context of health ... The social inequality of Aborigines [is] directly related to their dispossession, [and] is characterised by poverty and powerlessness. (Thompson 1989: 182)

The record of colonialism and dispossession is an account of not only the nineteenth but the twentieth century, continuing in certain places and respects until at least the 1980s. It is beyond the scope of this chapter to detail that history. Suffice to say, and as Kidd's study of the 'management' of Aborigines in Queensland (1997; see also Kidd, 2000) makes abundantly clear, there has been nothing mysterious about 'the processes by which dispossession is transformed into disease' (Reid and Trompf, 1991: xv). A nomadic hunting people was forced into fixed settlements without adequate waste disposal or housing, in groupings which did not respect tribal, clan or language affiliations, away from sources of food and economic resources and so into forced dependence on government or 
mission 'charity', with literally starvation rations, and little education or medical attention. In a fairly typical government communication, the medical superintendent of an Aboriginal reserve in the 1930s, noting the very high death rate from malnutrition and infection among children and the elderly, wondered whether it was 'worth trying to save them' by the provision of standard nutritional supplements (in Kidd, 1997: 101). Families were separated 'for their own good', in many cases native languages were disallowed, and almost every aspect of people's private and public lives was controlled. In Queensland, until 1986 for those Aborigines in state settlements, individual earnings, incomes and often bank accounts were mandatorily managed by state bureaucrats - in contravention of labour legislation - to the great benefit of state coffers. These circumstances have led quite simply and directly to the chronic poverty and disease patterns which afflict much of the Aboriginal population. '[G]overnments made themselves responsible' for Aboriginal people, punishing those who sought to run their own lives. And we know the results of this century of government controls: an appalling deficit on every social indicator' (Kidd, 2000: 6). What is remarkable here is the incidence not of disease, but of survival.

The Human Right and Equal Opportunity Commission (HREOC's) report into the provision of water and sanitation services to Indigenous communities draws one example of the underlying link between the dispossession of Indigenous people and their present lack of access to or control over services:

The conflict between European settlement and Australia's Indigenous people was not only a clash of cultures but a basic competition for land and resources. One of the most important resources was water. The opening up of Australia for 'settlement' and 'economic development' saw the beginning of a conflict over water which continues today. Aborigines were dispossessed and reduced to remnant pockets of population on the outskirts of European settlement. Aboriginal resistance was crushed by whites seeking river frontage and isolated water-holes. Today the same people are drawn into protracted negotiations to gain living area ... adjacent to water supplies or to improve water supply and sanitation in remote communities. (HREOC, 1994: 6)

However, from this broader history of destruction, two other responses to the question of Aboriginal health emerge, and it is with these that much of the following discussion is concerned. The first response is in terms of what are understood as welfare rights and the second in terms of rights as a process of mutual recognition or participation in political life. These two responses are interwoven, but they are also in some respects contrary to each other. The first focuses on the provision of services which all Australians, with some provisos and conditions, can claim as positive entitlements of membership of the Australian community. This response understands rights as bundles of entitlements to particular welfare goods that go, in this case, to make up public health. 
In practice, this remedy is cast as the extension of given services from the settler to the Indigenous community, from those who have to those who do not have. Ideally, these services should be extended in a culturally sensitive manner and with all duty of care. In practice, the extension of services to Aboriginal communities degenerates into 'welfarism', where those who 'have not' become passive recipients constituted as incapable and incompetent, and those who 'have' as overburdened (HRSC, 2000; Pearson, 2000). As the welfare system is more generally wound back, the tensions in this approach become even more tightly strung. Access to entitlement becomes 'charity' in a degenerate sense of the word, the services become a fixed commodity and the transaction itself fixed and one way, serving to widen the gap between recipients and others. Welfare becomes 'income provisioning for people dispossessed from the real economy' (Pearson, 2000: 7). ${ }^{1}$

The degeneration of 'welfare rights' to 'welfarism' is not inevitable. Although some areas of general welfare remain highly susceptible to 'welfarism', across much of the non-indigenous population welfare retains a sense of reciprocity. It is a process of modest redistribution to which one contributes and from which one draws, which allows also for those unable to contribute at all. The claim for public services is not a request for charity, but for due recognition as a citizen. The claiming, however, occurs within and is made possible by a broad construction of the state and of citizenship that is not entirely fixed but is certainly not open-ended. Claiming entitlements is calling upon an exchange the parameters of which are already in place. Its function is not to renegotiate or reflect upon political relationships but to exercise more fully already established norms and trajectories (although the mix of actual entitlements may be renegotiated). The construction of citizenship in operation here is one that, through the history of formalising norms of equality and fairness as well as of sovereignty, has assumed and required key thresholds of uniformity - what James Tully (1995) calls the 'empire of uniformity'. Homogenising ideals of citizenship had been overtly imposed upon Aborigines under earlier policies of assimilation: 'the legislative acceptance of Aborigines as citizens was long contingent on behaviours which demanded a denial or suppression of identification as an Aborigine' (Hunter, 1993: 257).

There are numerous accounts of the requirements Indigenous people had to fulfil to attain state (provincial) 'citizenship' or to have removed some of the legislative restrictions governing Aboriginal life that were in force until, in some areas, the early 1980s. Up until the early 1960s a Queensland Murri, ${ }^{2}$ for example, may be required to sign a declaration at the local police station stating that he or she would no longer associate with Aborigines. In West Australia an Aboriginal applicant for provincial 'citizenship' had 'to furnish ... two recent references from reputable citizens certifying his good habits and industrious habits. The magistrate had to be satisfied as to the fact and duration of adoption 
by the applicant of "the manner and habits of civilised life"' (Hunter, 1993: 257-8). Good health was a further indicator of 'civilised life', as was eschewing the company of other Indigenous people, and a specific requirement of citizenship. 'Should [the applicant] subsequently contract any of the diseases described [communicable diseases] ... or fail to adopt the manner and habits of civilised life, the Certificate [of citizenship] could be suspended indefinitely or cancelled' (Hunter, 1993: 258). Such requirements have been legislatively overturned, but they were arguably articulating much more powerful and historically embedded norms of political community as well as habits of administration. One is a member of the Australian community, just like everybody else, and can therefore claim access to certain entitlements, just like everybody else. This theme of 'equity' demanding uniformity has now been picked up by significant right-wing political trends.

The implicit price of access to 'ordinary' levels of welfare - education, housing, health, infrastructure - has been assimilation, if now resting on a less brutal body of requirements. This orientation seemingly remains a, and perhaps the, dominant functional approach despite the enunciation of goals of selfdetermination for Indigenous people, 'reconciliation' or even simply multiculturalism. Self-determination, reconciliation and multiculturalism can and have proved to be very difficult to grasp, particularly if the goal is one of administering an already complex service network. But part of the anger and confusion in sectors of the bureaucracy and the settler population concerning the failure of welfare delivery seems to be directed at the 'failure' of Indigenous people to be 'just like everyone else'.

But, like various groups within contemporary Australian society, Indigenous people are not 'just like everyone else'. Moreover, the problems they face are often systemic and structural, not individual. Even more potently, the structures and institutions from which they may claim entitlements emerged and were elaborated to the exclusion of Indigenous people and indeed on the basis of their dispossession. As a small minority with little economic, industrial or political power, Indigenous peoples and our interests are already easy to overlook but our marginalisation is not just a problem of numbers - it lies at the heart of the way Australia developed and functions as a modern nation' (Dodson, 1995a: 43).

Predominant responses to continuing disease patterns within the Indigenous population have focused on arguing the need for better provision of welfare services. The claim by Indigenous people of their right as citizens to better health provision is an important part of the effort to improve health standards and also, more broadly, of the struggle, underway since at least the 1950s, to claim effective citizenship. But these efforts may themselves remain inhibited within a too restrictive understanding of citizenship and political community. The second 'answer' to the question of Indigenous health, then, is that casting the question 
in terms essentially of welfare entitlements has proved an insufficient response to the alienation and exile of Aboriginal people within their own place; in degenerating into 'welfarism' it has effectively deepened that exile. But rights and citizenship are not reducible to welfare, far less welfarism. The second answer endeavours to address more directly some of the fundamental constructions of political community that continue the exclusion and dispossession of Aboriginal people as shaping Aboriginal ill-health. It is thus an effort to approach questions of self-determination more openly: it focuses not on welfare entitlements (which are themselves a function of citizenship) but on rights understood as the fundamental power to participate in the organisation of political community. Effective access to welfare entitlements is in part a consequence and a demonstration of this more fundamental power to participate. ${ }^{3}$

'Self-management' and 'self-determination' have themselves become policy terms within the health and welfare arena, and refer to various mechanisms to include Indigenous input into health administration. While important, such efforts have been limited in practice. ${ }^{4}$ Significant improvement in health for Indigenous people is likely to depend upon the growth of a more far-reaching and open-ended sense of self-determination - one centred on Indigenous communities taking, and being recognised as having, responsibility for the on-going task of defining and pursuing their own well-being in interaction with the broader dynamics of Australian political institutions and concerns. Rather than the extending of a commodity from one to another, this is a process of negotiation and a means of listening to and working with difference, whether at grassroots level, in the operation of a particular clinic or health promotion programme, or at broader levels that may change social practices for non-indigenous as well as Indigenous people. 'Whether guided by self-determination, self-management, or their successors, the promulgation of policy and development of programs [require] a wider understanding of social change that acknowledges both traditional and conventional needs of Aborigines, in a society that contains both Aborigines and non-Aborigines' (Hunter, 1993: 264).

There is nothing new about this remedy. Aboriginal people have been publicly agitating for what, essentially, is a recognition of themselves as participants in shaping Australian political and social life since at least the 1930s. The Aboriginal Tent Embassy on the grounds of Parliament House in 1972 was a symbolic assertion of a real difference and a call for the mutual respect from which negotiation could begin. The calls throughout the 1980s and again since the beginning of the new century for a treaty between Indigenous and settler Australia are moved by a similar logic. The search for reconciliation can also presuppose the recognition of difference as a legitimate element of political community. There has been debate since at least the 1980s concerning possible forms of Indigenous self-government. The RCIADIC (1987-91), the most comprehensive inquiry into the lives of Aboriginal people, saw the self-determination and 
empowerment of Indigenous society as the fundamental means by which Aboriginal people could overcome the inequality and disadvantage which distort their lives. 'There is no other way. Only the Aboriginal people can, in the final analysis, assure their own future' (RCIADIC, 1991: Vol. 1: 16).

Since 1967, and more particularly since the mid-1970s, the Commonwealth Government has mounted policies aimed specifically at bringing Indigenous health to the same level as enjoyed by other Australians. Moreover, since the mid-1980s there has been unprecedented media attention given to Aboriginal issues, including health. It seems that 'millions' are spent annually on indigenous health but with very little result. The statistics of Aboriginal health are thus widely seen as 'mystifying because Australian taxpayers, over the past 20 years at least, have always provided generously for indigenous Australians'; and they are shocking 'not only because of the human tragedy but also because taxpayers simply have assumed a better return for their money' (Jones, Northern Territory News, 20 March 1994: 16). The obduracy of patterns of ill-health thus become not the consequence of a history of management, but another sign of the 'Aboriginal problem' - a graveyard of politicians, bureaucrats and well-intentioned liberals. 'Endemic poverty, trashed housing, unemployment and alcohol-related violence and despair are portrayed as aspects of an "Aboriginal problem" which seemingly defies resolution' (Kidd, 1997: xix).

Leaving aside the misleading politics of demands for equality of expenditure rather than equity of outcome, however, the appearance of vast expenditure on Aboriginal and Islander people is misleading. Comparison of government expenditure on Indigenous and non-Indigenous health is complex, and reliable figures only started emerging in the late 1990s. According to John Deeble's 1998 study, only approximately 63 cents per head is spent on Indigenous health care for every dollar outlaid on the health of other Australians, and 'only a portion of the sixty three cents is spent on culturally acceptable and effective services to Aboriginal people' (quoted in Hunter, 1999). This is because Aboriginal people are not accessing Medicare (the national medical rebate scheme) or government-supported pharmaceutical schemes. The "model of short consultations in a private practice setting does not fit with the needs of Aboriginal people for holistic, comprehensive care in a culturally appropriate setting' (Hunter, 1999; see also Anderson, 1994). Specially targeted expenditure on Aboriginal health thus far has not come close to compensating for what they are missing in the way of primary health care services widely available to the general community. Not making use of general primary health care (for a variety of reasons), Indigenous people often wait until they are severely ill before seeking treatment, leading to a high rate of costly medical crisis interventions. Moreover the cost of delivery of many medical services in outback Australia, where a significant percentage of the Indigenous population live, is inevitably much higher than the cost of delivering the same service in an urban centre. Thus 
comparatively little is actually spent on Aboriginal health care, and little effective primary care is actually reaching Aboriginal people.

The actual quality of service delivery or of the welfare rights offered to Aboriginal people, and the monies expended on Aboriginal health, are further investigated in relation to Commonwealth health policies (pp. 182-8). But first it is important to consider briefly the more fundamental failure to accept Indigenous people as genuine interlocutors in political community. Both of the answers just considered to the 'question' of continuing Aboriginal ill-health have light to shed on the problem. The section following explores further both responses - which complement but are also in tension with each other - through a discussion of the construction of Aboriginal society as a lack and as a problem, and the twentieth century's predominant response to that problem: institutionalisation.

\section{'The great Australian silence'}

The 1992 Australian High Court decision on Aboriginal land rights, known as the 'Mabo decision', overturned the legal categorisation of Australia as 'empty land' (terra nullius) and recognised within Australian law the legal title to traditional lands of Australia's Indigenous people. The categorisation of Australia as terra nullius was established in 1788. Terra nullius was an international legal term signifying that the land in question belonged to no one, either because it was literally unoccupied or, as in the case of Australia, was not established as a form of possession in a manner recognisable to the colonisers through a system of local law or transformation by labour. The country was indeed seen to be populated, but by people who were not understood to constitute a 'society'. The doctrine of terra nullius acted as an erasure of Indigenous people as potential interlocutors, and as a powerful assertion of their total exclusion from negotiation, mutual interaction or 'the need to deal'. Terra nullius thus became both the international legal basis for the British assertion of sovereignty over the land of what became Australia and a statement of the legitimacy of British occupation. The two other forms by which sovereignty could be sought - conquest or treaty - were both in principle predicated upon the recognition of a society that was already in place, featuring a system of law, ownership of land and a form of political order. Territory acquired through conquest or treaty could thus be declared constitutionally subject to, in this instance, the British crown, while remaining the actual common law property of the colonised people. The recent high court debate over land rights was about whether Indigenous Australians could claim this common law title.

In terms of legal access to actual rights to land, the decision was highly conditional: the 'deepest significance of this decision on native title lies, not in its implications for property law', but in its profound implications for, and 
challenges to, Australian political and constitutional life (Dodson, 1995a: 96). This challenge is to both historical and contemporary conceptions of Australian political community and constitutional order. The judgment recognised that it was the 'dispossession [of Aboriginal people that] underwrote the development of the nation' (Brennan, in Dodson, 1995a: 43). Moreover, in recognising native title, the common law recognised and 'made room for a kind of law that had its roots outside the system' (Webber, 2000: 69). In so doing, the Mabo decision accepted Aboriginal society as a continuing (although by no means discrete) political and legal order. "Mabo ... said: "You have a place to engage, you have a place in this country and that place is guaranteed under the rule of law", (Pearson, in Weekend Australian, 8-9 November 1997: 26). The recognition of native title is thus

about the co-existence of partially autonomous societies, each with its own system of law, that must in some fashion good or ill, relate to each other. Because of the challenges of adjustment - because of the sometimes profound differences of context and forms of social ordering - that process may only be achieved through mutual accommodation over the very long term. (Webber, 2000: 70)

It is now at least a legal and constitutional potential that 'Australian nationhood is no longer forged within an exclusively non-indigenous crucible' fuelled by 'a vision of a single people' but through a broader, more open, conception of participation (Webber, 2000: 77, 88).

The Mabo (and the Wik) decision also focused attention emphatically on a fundamental element of the greater history of Indigenous and non-Indigenous interaction and the colonisation of Australia. This is the issue of what Stanner called 'the great Australian silence' (1969: 18), that is, the settling over time of Australia by non-Aboriginals 'on the basis that there was no need to deal with the indigenous inhabitants or even acknowledge their laws, their rights or their interests', or indeed their existence (Nettheim, 1993: 104).

The means by which 'land' was recognised as 'property', crucial to the assertion of terra nullius, is significant here. For the British colonists, following Locke and, later, Tocqueville and other theorists of the state (as mentioned in Chapter 2), ownership of land was established by cultivation 'defined in terms specific to European agriculture' (Tully, 1995: 73). Australian Aboriginals were hunter-gatherers and, not being engaged in fixed agriculture, did not have a system of settled individual land ownership. Like the Amerindians they 'occupied but did not possess the land. It is by agriculture that man wins the soil' (Tocqueville, in Connolly, 2000: 185). Indigenous peoples were 'in a state of nature'. Stable property is a fundamental element of Lockean contractarianism. The need for protection of property and for resolution of disputes concerning it is one of the prime motivations for men to enter into contract, so establishing a system of laws, of magistrates and of sovereign powers. Moreover, 
a system of individual land ownership and sedentary agriculture is seen, in this account, as the basis of a surplus economy and an increasingly complex economic life. Property thus functions as an essential foundation of both political life and economic well-being - as enabling and underpinning 'civilisation' in the form of the state. Being by definition without property, Aborigines had thereby not entered a contract and so did not constitute a society. They were seen as a 'people without politics' (according to the anonymous anthropologist quoted in Langton, 1994: 132), without law or the supposedly civilising influence of a complex market economy, with 'neither nationhood nor territorial jurisdiction' (Tully, 1995: 72).

According to this powerful and pervasive account of political community, Indigenous peoples represent the prehistory of political life - the world before crossing the threshold of the social contract into the state. Here the imperial powers of Europe represent the highest and most developed point in a natural trajectory of human civilisation. They are at the endpoint - or almost there where humanity meets its potential. Indigenous people are primitive waystations or cul de sacs which had already been overtaken, experiments that had not altogether borne fruit, dead water that now, given the opportunity, would naturally flow into the great stream of civilisation - or dry up. Moreover, through this vision of mounting stages of civilisation, and by virtue of the supposed economic inefficiency of hunter-gatherer life, it was - and often still is presumed that Aboriginal people essentially benefit from the seizure of their lands and the destruction of their manner of life, for then they can be assimilated into civilisation. This indeed was explicitly part of the argument for removing mixed-race children from Aboriginal parents. While certainly not the only way of approaching Aboriginal peoples - some settlers resisted the violence towards and the exploitation of Indigenous people - it was the predominant way. Tully, commenting on Locke's justification of the colonisation of North America, points to a pattern equally relevant to the later colonisation of Australia. Locke's account replaces the long, painful history of conquest, destruction and betrayal of Indigenous Americans 'with the captivating picture of the inevitable and benign progress of modern constitutionalism' (1995: 78).

The picture of the progress of modern constitutionalism was only deepened by the emergence in the nineteenth century of social Darwinism. This doctrine elaborated a division of the human species into superior and inferior races in which 'the superior races have a right, because they have a duty . . . to civilise the inferior races' (Ferry, in Cowie, 1986: 47). The land 'offers itself not to the isolated, ignorant man of the first ages, but to man who has already mastered the most important secrets of nature, united to his fellows, and taught by the experience of fifty centuries' (Tocqueville, in Connolly, 2000: 185). Indigenous people were now believed to be a biologically as well a as socio-politically more primitive stage of human evolution - 'mankind in the chrysalis stage' (Sir James 
Frazer, in Stanner, 1969: 35) which would naturally pass away when faced with the reality of modern man. Thus for almost a century it was believed that Aborigines would simply die out. Events appeared to bear out this presumption, with the severe depletion of the Indigenous population through introduced diseases, killings and enforced changes of lifestyle. The "expected disappearance from the face of the earth [of Aboriginal peoples] was merely a case "following the order of the world, the lower race preparing a home for the higher", (Dodson, 1993: 44, quoting Stanner). The full membership of Aborigines in the human race was a point of real anthropological, medical and popular debate. As a result there was relatively little official attention paid to understanding the circumstances of Aborigines, including their health status, for 'as long as the extinction of the aborigines was assumed to be inevitable (and as late as the 1930s the historian Hancock could still speak of their "predestined passing") no information could have had much more than a poignant irrelevance' (Stanner, 1969: 37-8).

After surveying histories of Australia written between the 1930s and the late 1960s, for example, Stanner concludes that 'inattention' to the Aboriginal community in Australian histories was 'a structural matter, a view from a window which has been carefully placed to exclude a whole quadrant of the landscape' (1969: 24). The Immigration Restriction Act was one of the first bills to be passed on federation and it formally inaugurated the raft of measures known as the White Australia policy. This policy, which remained in force until 1967, expressed a key social and political aspiration - an egalitarianism of white male workers from which Aboriginal people were by definition erased. The exclusion of Indigenous people from full legal citizenship and census-taking until overturned by referendum in 1967, after the great influxes of post-war migration, gives some indication of the political realities of this silence and the extent of Aboriginal powerlessness within the Australian community.

Terra nullius was a formal legal expression of this exclusion which formal legal citizenship did not override. Citizenship could stand as an assimilationist presumption, even after that goal had been officially repudiated. Terra nullius remained as an assertion that Aboriginal society had no political existence, no pattern of law or binding relationship within which 'rights' or indeed real community could be located, other than those conferred upon individual Aborigines by absorption into civilised ways. This stands in contrast to migrants, who had culture and politics - even if their source was elsewhere and often regarded with prejudice. Aborigines were those upon whose absence the presence of the settler society was founded and upon whose inferiority, evolutionary closure and natural disappearance from history the blossoming and vigour of Australian political life was predicated and justified. The significance of the Mabo and Wik decisions lies in the overturning, in the legal and constitutional spheres at least, of these presumptions. 
This 'overlooking' and erasure of an Indigenous people does not mean that no attention has been paid to Aborigines. On the contrary, Aborigines have stood as exemplifications of shifting categories within the settler colonial culture - noble savages, vermin, children and, latterly in some quarters, victims. Their exclusion has constituted a very particular and compelling place, for it was precisely the 'failure' (however conceived) of Aboriginal people that legitimised white possession of the country. It is not surprising, then, that Indigenous people have been constituted as a lack, an incapacity and a 'problem' (this is evident in the high incarceration rates of Aboriginal juveniles for minor offences) - 'a doomed and primitive race who were not part of Australian society except as recipients of non-Aboriginal benevolence' (RCIADIC, 1991: Vol. 2: 5). At the same time, they are a threat and an otherness whose lawlessness and disruption is to be feared. How to handle this 'people as problem' has led over the past century to successive forms of institutionalisation.

'Invisibility' and institutionalisation have constituted the conditions within which Aborigines could pursue their well-being within the context of the dominant Australian society. The institutionalisation of Aboriginal people has proceeded since the mid-nineteenth century under a variety of policy settings and intentions - segregation, assimilation, integration - and, arguably, continued under more recent policies of self-determination. Institutionalisation frequently involved a process of centralisation, 'despite the small-group orientation of traditional Aboriginal societies' (Hunter, 1993: 259), with the location, size and composition of the community usually determined according to ease of administration by the state rather than clan or group affiliation. It enforced a "change from small, semi-nomadic communities into large aggregations of people from many different areas [and so] led to a rapid increase of both communicable diseases and social tensions resulting in physical violence', as well as degraded dietary habits (Reid and Trompf, 1991: 385). The reserves were authoritarian in structure and not integrated into the broader economy.

The effect of institutionalisation has been to establish an astonishing degree of control over Indigenous people's lives by state institutions or bodies (such as missions) run in broad terms on behalf of the state. Over generations, this process has created conditions of extreme and enforced dependence. 'Diet, movement, employment, marriage, child-rearing arrangements, and the exercise of religious belief were all subject to the wishes of the mission or settlement custodians' (Reid and Trompf, 1991: 385). To give an example, a study of infant and child mortality between 1967 and 1969 in communities under Queensland Aboriginal Affairs Department's control found that malnutrition was the key factor in infant mortality and the chronic ill-health of the surviving children. The study drew attention to inadequate medical attention and 'defective social indices', such as income and housing. The official response included appointing liaison officers to target 'parental incompetence'. The liaison officer was to 
oversee health and hygiene but also to pursue rent arrears, " "acquire a knowledge of all the individual residents", transmitting to head office "their names, where they live, how they care for their families, standard of housekeeping, work record, personal problems and difficulties, particular abilities and any other material that may be of value" ' (Departmental communication, quoted in Kidd, 1997: 261, 262). Parents deemed 'incompetent' might have their children removed. Not surprisingly, compliance with the liaison officers was low. 'Liaison officers...effectively acted as agents to advance the implementation of the state's assimilation policy at an individual level . . . the more "advanced" or "suitable" families were given access to the new housing and the more impoverished or destitute were passed over' (Kidd, 1997: 263).

The RCIADIC found that the level of control exercised over Aboriginal lives

was no less brutal for the fact that the policies which achieved the control were often justified by their authors on humanitarian or paternalistic grounds... [Those whose deaths were investigated by the Commission] all had files - in many cases hundreds of pages of observations and moral and social judgements on them and their families; considerations of applications for basic rights, determinations about where they could live, where they could travel, who they could associate with, what possessions they could purchase, whether they could work and what, if any, wages they could receive or retain. Welfare officers, police court officials and countless other white bureaucrats, mostly unknown and rarely seen by the persons concerned, judged and determined their lives. The officials saw all, recorded all, judged all and yet knew nothing about the people whose lives they controlled. Aboriginal people were removed at the whim of others, crowded into settlements and missions and in impoverished camps on cattle stations. Always there were non-Aboriginal people giving orders, making decisions in which the opinions of the Aboriginal people were not sought nor, if volunteered, heeded. Aboriginal families could be separated, children removed if judged too light skinned, placed in homes or boarded out as servants of non-Aboriginal families . . This control - these horrors of subjugation - were still occurring in the 1960s and for much of the 1970s. (1991: Vol. 2: 502-3)

\section{Commonwealth Indigenous health policy - 1970s-2000s}

Aboriginal people throughout the country were formally registered as Australian citizens and included in the census in 1967, following a national referendum. This was the result of increasing Aboriginal civil rights activism, growing sensitivity to issues of race relations within sectors of the nonindigenous electorate and increasing international debate on issues of colonisation and racism, with many newly independent states being sharply critical of those countries, like Australia, where Indigenous people were not full citizens. The decision was a clear win for those groups, in particular Indigenous groups, which had been fighting to overturn this particular assertion of black 
invisibility. For many Aborigines, this shift opened the way for '[i]deas of autonomy, self-determination and sovereignty [to become] central ... In this new era the key issue became how Koories would exercise their rights to health care' (Anderson, 1994: 34). In 1971, Aboriginal people established the first Aboriginal Medical Service (AMS) in Sydney, staffed in part by Indigenous people and dedicated to serving their health needs. Aboriginal Medical Services, which aims to provide community controlled primary health care, has subsequently become one of the fundamental elements of Aboriginal health care throughout the country, with some hundreds in operation.

The crucial practical effect of the 1967 referendum was that it meant that, for the first time, the Commonwealth (rather than the state governments) had power to legislate on Aboriginal issues, extending to authority to override the states. Persistent and at times savage jurisdictional dispute is a standing feature of the Australian federal system. Up until 1967, 'Aboriginal Affairs' had been overwhelmingly the province of local state governments. After 1967, the fact of citizenship added another tier of government and funding - one regarded with deep suspicion by the states but which provided greater leverage to Indigenous groups pressing for change.

In practice, however, a more substantial focus by the Commonwealth Government on Aboriginal health did not emerge until after a change of federal government in 1972, with 'self-determination' for Aboriginal people being adopted as a policy goal by the new Labour Government. In 1973, the first National Plan for Aboriginal Health was released. This plan envisaged that within ten years Indigenous health would achieve levels broadly consistent with settler Australian health. State and territory governments, however, refused to endorse the plan. It is not surprising on any level, then, that despite some positive achievements the plan failed, and in doing so demonstrated issues that ever since have characterised government health policies for Aborigines. On administrative grounds, alone, the plan failed because of lack of coordination and cooperation among levels of government, and lack of commitment on the part of the federal government to push forward its policy goals against resistance from state or local governments; because of inadequate funding; because it did not have or provide tools with which to grasp the extent or nature of the problem; and because of the kind of medical intervention that, in the main, it was designed to provide. It is interesting to note, almost thirty years later, that the first paragraph of the most recent government report into Indigenous health states that 'the planning and delivery of health services for Indigenous Australians is characterised by a general lack of direction and poor coordination', with no delineation or agreement among different levels of government concerning their responsibilities (HRSC, 2000: 1).

In retrospect, the 1973 plan appears no more than a statement of intent. As was argued earlier, grappling with the nature of Indigenous ill-health 
involves engagement with Aborigines as people with whom political community is shared. This is a difficult and challenging process. But even at the technicaladministrative level, one of the simplest tools necessary for coming to grips with Aboriginal ill-health - information on mortality and morbidity patterns and their social as well as medical contexts - has to a significant degree been unavailable. It is perhaps not surprising that, after decades during which the issue was ignored, there was little information on Aboriginal ill-health's extent. However, the first effort at a genuinely national database on Aboriginal health was not released until 1997, almost twenty-five years after the National Plan. Lack of information not only continues a level of ignorance about specific patterns of ill-health and disease, and about Aborigines' identification of their own health priorities, it buries the simple and evident connections between Aboriginal disease and Aboriginal history as well as information on the state of service delivery and the on-going experience of discrimination. Lack of reliable information also contributes to the powerful popular misconceptions that Aborigines are funded to a level well in excess of that of the 'ordinary' Australian and that continuing destitution and ill-health are a mysterious function of 'Aboriginality'. It allows the charade of government ministers regularly 'discovering' black living conditions and the attendant, perhaps genuine, expressions of shock, with little to indicate a clear outcome, and repeatedly blaming the persistence of poor living conditions on official and community ignorance.

Despite this somewhat disingenuous cycle of ignorance and shock, the broad sweep of Aboriginal health problems and solutions has not been obscure. The first major official inquiry into Indigenous health, undertaken by the House of Representatives Standing Committee on Aboriginal Affairs (HRSCAA) in 1979, attributed Aboriginal morbidity to unsatisfactory environmental and public health, their low socio-economic status and the cultural insensitivity of much health delivery. It emphasised provision of basic environmental health care, particularly safe water supplies, the need for Aborigines to be involved at all levels of health care and for their effective self-management of health and well-being (HRSCAA, 1979). These findings are notable in that they are consistent with the recommendations of all subsequent official inquiries into and major official statements concerning Indigenous health.

In the administrative domain, the division of planning, responsibility and funding between levels of government and across diverse departments and instrumentalities has been of immense detriment to Aboriginal health. While the Commonwealth has led policy development and provides the majority of the funding, health delivery remains primarily a state and territory responsibility, while the provision of the most basic services - water, sewerage and so on - has to a significant extent rested with local councils. The Commonwealth funds much of the provision of essential services, but plays no part in the actual allocation of funds on the ground. Accountability for expenditure appears vague. 
According to Aboriginal health workers, clinics may have to deal with up to eighty different bureaucracies split among three levels of government. And the jealousy endemic in Australia's federal system has allowed lines of responsibility to blur and disappear. This fragmentation is compounded by the absence of an agreed plan or of close coordination among policy-making bodies. Thus, despite the 1973 plan, there was no coordinated strategy for actualising intentions articulated for Aboriginal health until the release of the first National Aboriginal Health Strategy (NAHS) in 1989. But the Strategy was not able to overcome the difficulties created by the fragmentation of responsibility, and the lack of long-term planning and accountability for outcomes.

The next Strategy, announced in 1994, was itself quietly abandoned less than two years after its adoption, leaving no clear trail of what had actually happened to many of the programmes planned or the monies promised. A case study of the 1994 Strategy by Access Economics called it a 'budgetary illusion' which created the impression of new programmes and major additional funding - and so either an image of social policy commitments or more 'waste on blacks', depending on your view - through the misleading representation of on-going running costs as 'new monies' (Access Economics, 1994). The 2000 HRSC report still warns that 'lack of clear delineation of responsibility [for] Indigenous health is . . . an incentive for the parties, particularly the States, to indulge wherever possible in shifting the onus for payment to [another] sector', while Recommendation 1 is still a call for the Commonwealth to actually accept responsibility for primary health care for Aborigines (HRSC, 2000: 2-3). ${ }^{5}$

Lack of coordination leads to buck-passing between funding bodies, confusion among those working directly with people's health and a convenient cover for dishonesty over funding. It leads also to intense competition for the too scarce 'Aboriginal health dollar' among different aspects of health, and to programmes working at crossed-purposes. Thus, providing better housing, a fundamental aspect of environmental health, "has led in some communities to a decline in health status. This has resulted from a reduction in disposable income as a consequence of increased rental and utility charges and a decrease in funds for foodstuffs, in turn leading to undernutrition and greater susceptibility to infection' (Saggers and Gray, 1991: 392). Moreover, Commonwealth funding for housing and essential infrastructure for disadvantaged Indigenous communities comes under its indigenous health budget whereas similar services for non-indigenous communities are provided under a range of other budgets. This adds to the misleading impression that large sums of money are spent on Aboriginal health. With no clear lines of responsibility many programmes at federal and state level simply fail to eventuate, although by that time public sensitivity over the 'costs' of the Indigenous population will have been fed. The results of jurisdictional rivalry and subversion, of budgetary and electoral manipulation, of lack of 
coordination and accountability are regularly bemoaned as yet another dimension of the 'Aboriginal problem'.

As well as the impact of administrative fragmentation and sleight of hand on Aboriginal health delivery, government endeavours have also been limited by a general failure to approach Aboriginal understandings of what might constitute well-being and so, as a result, by the misplaced or inappropriate nature of much medical intervention. Building on a long history of approaching Aboriginal health as a policing matter, often aimed at protecting the white population from communicable diseases, the dominant contemporary approach has been one of 'medical problem solving' aimed at 'taking over' a particular moment of health. For example, one particular area of focus under the 1973 plan was infant mortality, where rates of death paralleled the worst recorded anywhere in the world. Results here demonstrate both the successes and the limitations of the dominant medical approaches to black health. Due to highly focused medical intervention, infant mortality rates fell significantly, particularly in rural areas. This has largely been the result of Western medical techniques taking over, holus-bolus, the actual delivery. So, for example, in some regions pregnant Aboriginal women are transported hundreds of kilometres to the nearest hospital for their confinement. It is not simply that this technique of delivery is deemed culturally inappropriate (and frightening) by many Aboriginal women, offending traditional women's law and isolating women from family support at a time of vulnerability; it also leaves the mortality rate, after almost thirty years of intervention, at two to three times the rate of settler infants (and maternal mortality at five times the rate of the general population). Moreover, 'such focused health interventions have not solved the problems of ill-health in Aboriginal children. Rather, they have changed the nature of the problem. The children of impoverished Aboriginal parents no longer die in infancy. Instead, many survive, but "fail to thrive", (Saggers and Gray, 1991: 409). The Royal Commission into Aboriginal Deaths in Custody described the "pleasing reduction in Aboriginal infant mortality' as an example of 'improving the indicator rather than improving the quality of life ... What may appear on the basis of a particular indicator to be a real achievement may, in fact, reflect simply an improvement in one narrow area rather than any substantial improvement in the quality of life' (RCIADIC, 1991: Vol. 2: 51). ${ }^{6}$

The limitations of 'taking over' a moment of health in this way are a consequence of both cultural difference - the contexts of meaning within which people situate their lives, their family relationships and their well-being - and power: "medical interventions are not value free ... [or] limited to the organic realm. Medicine is an agent of cultural change ... The body which enters the clinic is a product of organic and social processes which are so intertwined it's impossible to engage with, or intervene in, either realm without impacting on the other' (Anderson, 1994: 39, 40). 'Colonial' categories of Aboriginality still 
structure many health encounters for Indigenous people. The comatose diabetic, for example, is assumed by police and ambulance officers to be drunk and put in the lock-up where he dies from lack of medical attention. '[O]n a daily basis this tragedy is re-enacted, albeit on a more mundane level' (Anderson, 1994: 43). 'Experienced, skilled workers do make mistakes of this order when dealing with Koori people - not only because they lack technical knowledge but because their actions continue to be driven by a colonial view of Aboriginal Australia' (Anderson, 1994: 31). More broadly, an experience of health care which repeats the conditions of inequality, lack of autonomy and diminished self-respect which contribute to the original patterns of disease will work to negate the longterm value of the care provided.

Different beliefs and practices concerning the nature and causes of illness can profoundly influence the effectiveness of health care as well as contribute to the confusion of both parties and the alienation and humiliation of the patient. 'With the pervasive influence of Western medicine in Australia, it is easy to lose sight of the differing underlying health beliefs of sub-sections of the Australian population... Even among Aborigines living in cities and towns of south-eastern Australia current understandings represent an amalgam of Western and Aboriginal belief' (Thompson, 1989: 192). Aboriginal conceptions of health focus less on disease and intervention than on the dynamics of extended family and community well-being as part of a network of 'interrelationships between people and land, people and creator beings, and between people, which ideally stipulates interdependence within and between each set of relationships' (NAHS, 1989: ix). Moreover, following a diabetic diet or finding time for dialysis can be difficult when you are living in the social and economic conditions of many Aborigines. 'Is Aunty's dietary change only to be achieved by persistently telling her how to eat better? How might our strategies change if we focus on the family and not the individual?' (Anderson 1994: 43). Ian Anderson emphasises the need for doctor and patient to establish a consensus on how they will, together, approach the alleviation of suffering. 'Doctors must see that the extent to which people incorporate medical advice is not the responsibility of the patient alone. It's a problem of the doctor-patient relationship'. For Anderson, a Koori medical practitioner trained in conventional Western medicine, health practices in a community of both Indigenous and nonIndigenous people must involve processes of mutual recognition and negotiation of 'healing strategies' (1994: 42).

In this context the operation of the community-managed Aboriginal Medical Service is particularly important. A loose national structure of the AMS has emerged, with the National Aboriginal Community Centre Health Organisation (NACCHO) formed in 1997 as a peak body for the services. NACCHO has been negotiating framework agreements with key parties in health management state by state to assist the AMS to tame the absurdly fractured jumble of 
bureaucracies with which it must deal. NACCHO is consulted but not deeply involved in policy or funding decisions at state or national level and could not be called an equal partner in Aboriginal health delivery. Nevertheless, NACCHO is emerging as a major resource for governments and for Indigenous health, with the potential to work as a mediating body between governments and mainstream health delivery on the one hand and an expanded form of Indigenous self-managed health services on the other.

\section{Self-determination and citizenship}

Questions of self-determination and self-management are repeatedly determined to lie at the heart of Indigenous ill-health. Reflecting this, selfmanagement and self-determination have been the official policy orientations of federal health delivery programmes for the past twenty-five years. But what has self-determination meant? Clearly, it has meant different things in practice as well as in theory - too many to be considered fully here. For government administrative bodies, however, notions of self-determination seem often to presuppose either a model of a universally accessible space - that is, contemporary liberal notions of the universal man and citizenship - or, more mundanely, the protocols of bureaucratic meeting procedure. While certainly not without value, these models are neither neutral nor universal. Put differently, the structure of bureaucratic consultation tends to reflect bureaucratic norms, not Aboriginal communication patterns. Or notions of self-determination may emphasise models of development, which have "emerged as a Western panacea for the inequalities continuing in the aftermath of decolonisation' (Hunter, 1993: 267). But either way and despite effort at consultation, the question becomes stuck in the confusion of trying to 'deliver' self-determination as a service. 'Regardless of the political rhetoric of opportunity and empowerment, under whatever policy or platform, the structuring of Aboriginal lives continues. To suggest that this will not occur in the era of self-determination and selfmanagement denies the institutional reliance on such policies and programs' (Hunter, 1993: 267). Indeed, despite ‘de-institutionalisation', it seems that

the control remains just as effective today whatever may be the rhetoric of government ... [Many Aboriginal people] would say that economic dependence upon government and the restrictions placed upon them by discriminatory practices achieve the same result - their lives are controlled by others who share neither their culture nor their perspective ... because they have not shared their history. (RCIADIC, 1991: Vol. 2: 502)

Overviewing governmental social justice initiatives of the 1980s the then Aboriginal and Torres Strait Islander Social Justice Commissioner Mick Dodson observed that "self-determination, considered as a component of the Common- 
wealth social justice policy ... [has operated as] a welfare measure directed at Aboriginal and Torres Strait Islander peoples ... [which] rests on a policy decision taken by the Commonwealth Government about us' (1993: 43). Two years later Dodson warned: '[A]s long as the relationship between the state and Indigenous people is caught in a dynamic of dependence, any policy, no matter how you dress it up, will perpetuate the violation of our rights as peoples' (Dodson, 1995b: 20). Dodson argued that self-determination in fact turns on 'the great unposed question dividing Indigenous from non-indigenous Australians ... The essence of the matter goes to asking the question which has never been put to our people: Do you consent?' (1993: 51).

This paradox of administratively conceived (but underfunded) 'selfdetermination' turns the argument back to the two ways of responding to, and understanding the reasons for, Aboriginal persistent ill-health. The first is in terms of rights as entitlements: of the history of administrative measures and the need for improved service delivery and accountability. The second is in terms of rights as mutuality: of being recognised as a participant in the inevitably shared and uncertain processes of political and social life - of recognising Indigenous people as interlocutors who are both different and at the same time, as Aboriginal artist Sally Morgan pointed out, part of us (RCIADIC, 1991: Vol. 2: 44) ${ }^{7}$. The first response emphasises equitable access to essential social commodities; the second approaches Aborigines not as recipients but as participants in constructing not only their own but the broader political life of the country. This goes beyond the goal of cultural sensitivity to the recognition of a process of ongoing negotiation; beyond the distribution of material goods to the production of the categories and relationships of understanding, power and social order. It is here, in this difficult place, that the question of self-determination bites home. The two responses closely interweave (distribution of material goods, for example, naturally affects power, while real access to social capabilities is a matter of power). In so doing they touch on what may be the particular questions and challenges posed by Indigenous people to practices of citizenship and to notions of political community, at least within liberal states. That is, the issue of Indigenous health and rights to health care raises the question of how, in a liberal state, we understand the principles of 'participation' and 'consent', of how we construct statehood. It questions not 'Aboriginality' but the nature of political community.

Essentially, since 1967, the Australian population has been hedging around the issue of what citizenship for Aboriginal people might mean. Long-standing inadequate funding and a lack of government accountability and coordination, despite announced policy goals and commitments, not only raise questions about the operations of government, although these questions are pressing. These failings raise fundamental questions also about the capacity or the willingness of our political order to reach accommodations or to 'deal with' 
Aboriginal people rather than simply reduce them to 'problem' categories, failure, lack and threat.

Dodson puts the case for effective, rather than simply formal, recognition of Indigenous people as citizens who have entitlements. 'Policies and programs which rest primarily on a perception of need and powerlessness subtly reinforce the powerlessness of the recipients ... The recognition of entitlement is in itself an act of empowerment' (Dodson, 1993: 7). Effective citizenship and equal rights remain key goals. But they can also be ambiguous goals. With the slow repeal of much of the more draconian and exclusionary legislation and regulations throughout the country, Aborigines have been expected, as Aboriginal lawyer Noel Pearson suggests, to become simply 'black Australians'. Two elements of this expectation are relevant here. One is that models of citizenship can contain the assimilationist assumption (at times made explicit), referred to earlier:

The policy of assimilation means that all Aborigines and part-Aborigines are expected to attain the same manner of living as other Australians and to live as members of a single Australian community enjoying the same rights and privileges, accepting the same responsibilities, observing the same customs and influenced by the same beliefs, as other Australians. (Native Welfare Conference, in RCIADIC, 1991: Vol. 2: 510)

This is a model of citizenship as sameness and of entitlements as rights to that sameness. For most Indigenous people (as well as other social groups) it offers only the appearance, not the real possibility, of 'entry'. It turns on the crucial understanding that Aboriginal people are themselves 'other, something outside this - people not in fact part of this nation ... [and then it offers them] a chance to "fit in" . . by abandoning their particularity" (RCIADIC, 1991: Vol. 2: 511). Its goal is to treat what is different as the same and so to deny the process of negotiation and accommodation of difference and identity. The practical effects of this approach can be seen again and again in the actual dynamics of settler Australians' 'consultation' with Aboriginal people.

Assimilation has been officially repudiated, but the new models of 'selfdetermination' remain obscure. Efforts to provide Indigenous Australians with their entitlements, with 'access and equity', are eroded by the uncertainty of the non-indigenous population and institutions of what to make of Indigenous difference - or rather, of what seems to some an opportunistic mix of difference and sameness. Different relationships to land - in a sense, the crucial original difference - remain one of the more evident and disturbing encounters, particularly since the Mabo decision opened the way for Indigenous people to make claims to native title on certain categories of land. Facing the uncertainty of negotiating mutually acceptable and co-existing land uses rather than the certainty of a single unitary title has proved highly unsettling for many nonindigenous organisations and people. A choice between two options - neither of 
which is likely to be viable - seems implicit in the insistence on certainty. Indigenous people can be different - they can take their land rights (carefully delimited to protect non-indigenous mining, farming, commercial and electoral interests) and go home to, as it were, the remnants to work out their own health and other problems. Or they can be just like 'us' and play by 'our' rules. Caught somewhere between these poles, and despite the efforts and successes of particular programmes, the broad operational understanding of Indigenous health care has remained stuck in 'charity', dependence and welfarism.

Underpinning the real policy, conceptual and practical difficulties of effectively repudiating assimilationist constructions of citizenship, participation and equity may be a second element in the expectation that Indigenous people will become 'black Australians'. This is the construction of the person and of political community - broadly liberal and to some extent Lockean constructions upon which understanding of participation and consent are in part predicated. Here, as discussed in chapter 2, political community is imagined as ideally founded upon a universal public space which emerges literally or metaphorically out of the free agreement of rational people (the universal man) or through the operation of a universal proceduralism. 'Participation' thus tends to occur within boundaries already defined by particular and rather narrow models of the person and of community. But as the discussion of terra nullius suggested, the assertion of Australia as a state drew not on a slow process of accommodation with Aboriginal society but on classifying Aboriginal people as not rational, or incapable of political community or of the consent that, for liberal models of political community, underpins participation. The 'dispossession ... [of the Aboriginal people] underwrote the development of the nation' (Brennan, in Dodson 1995a: 43) not only because the killing and quarantining of Indigenous people made their land available for settlers and their economic activity, but because the construction of the state and of citizenship was in significant ways predicated on the constitution of the natives as outcasts, inferior, beyond community. Aboriginal people's relationship to the scope of 'universal man', and to the forms of citizenship or self-determination still within the ambit of this figure, remains at best ambiguous.

The processes available to Indigenous people to take part in citizenship have too easily become, then, akin to charity or to policing. The Queensland liaison officers, policing every aspect of those Indigenous lives under their purview in the 1960s and 1970s, could quite reasonably have considered themselves to be assisting Aboriginal people to claim their entitlements, overcome their disadvantages and participate in modern life. Policies of self-determination have not been able effectively to step out of this dynamic. The HREOC, commenting on the Act of Parliament which provides the key legislative underpinning for Indigenous rights in Australia, noted: 'The Racial Discrimination Act provides for "special measures" to be taken to redress disadvantage.' However, as it stands 
the Act "cannot adequately protect the cultural rights and the right to self determination of Aboriginal and Torres Strait Islander people. The reliance on the special measure provisions of the Act to justify different treatment implies that at some point special measures should cease and mainstream policies apply' (HREOC, 1994: 9).

This is the ambivalence of claims to citizenship and participation; it is also the ambivalence of notions of rights - an ambivalence that this the present examination has approached by referring to rights as both a way of asking questions and a form of answer which does not exhaust the question. Indigenous people claim citizenship, participation and rights - and doing so has made available significant political leverage as well as some access to resources. Perhaps more fundamentally it has provided Aboriginal people with one way of articulating their suffering, their self-respect and their aspirations to be treated with respect and to shape their own lives. The practices, language and institutions of citizenship and rights are certainly not monolithic, despite the power and persistence of the dominant models. The operation of the courts system, for example, both indicates the limitations of this key set of frameworks and practices to respond, in its designated place and moment of action, to systemic alienation and marginalisation, and has provided one of the most potent levers by which Aboriginal people can stake their own claim in Australian political life. But what is being fought over is not entry into a community of sameness, where a 'problem' people seem to just fail to make the grade, but a shift in the dominant constructions of citizenship, participation and rights.

Participation as the acceptance of mutuality is important because it is a rejection of the subtle assertion of an exclusionary sameness as the basis of political community. It is important also as a reminder of the need to work with difference and not quarantine it 'elsewhere'. One response to have come from both some Indigenous and non-indigenous people to the question of selfdetermination has been to assume that once Aborigines are on their land their other problems, such as ill-health, will evaporate; or that once whites are out of the way, Aborigines will return naturally to their traditional ways. But even leaving aside those many Aborigines with no real access to traditional lands, Aboriginal societies are in radical transition and traditional customs are not necessarily simply there waiting to be recovered. Interpretations of Mabo, for example, can have an anachronistic element, seeming to require Aboriginal people to return to a state of 'otherness', but the judgment was a recognition, not of native title in 1788 , but of its on-going vitality and place in contemporary Australian political life.

Self-determination, as Mick Dodson has pointed out, is a process. It is a process that does not flow simply from an original or foundational consent, but one that flows from the act of asking and listening, the work of negotiating 'every issue concerning the historical and present status, entitlements, treat- 
ment and aspirations of Aboriginal and Torres Strait Islander peoples . . . The right to self-determination is the right to make decisions' (Dodson, 1993: 41). Self-determination for Aborigines requires non-indigenous institutions and people to be prepared to enter the process that was originally denied - to negotiate, to accommodate Aboriginal people as part of the decision-making, to accept uncertainty of outcome and in some cases significant change in their own institutional patterns and practices. There is little sign of this preparedness in the current political climate in Australia, yet there is also a growing restlessness as evidence of pointless trauma, the violence of destructive policy and rifts between white and Indigenous accounts of the recent past become increasingly obvious and demanding of explanation.

While of great significance, the gaining of formal citizenship and the recognition of native title did not markedly affect health or education or custodial rates or indeed the life experiences of most Aboriginal people. The empowerment of some groups through, for example, gaining land rights does not automatically provide either the funds or the range of capacities needed to meet complex health needs. Claims to citizenship and real participation for Indigenous people, but also debate about the nature of citizenship, need to be pursued across each area of interaction. It is through the process of negotiating what self-determination might mean in regard to particular aspects of education, health, law, policing, land rights, and so on, that the practical constitution of intercommunal life in Australia can shift. Reconciliation, mutual respect or dialogue do not lay claim to an ideal or essential space of exchange; that requires the on-going effort to create workable spaces. In this sense rights as entitlements and as the mutual recognition that makes negotiation possible are entwined. The enjoyment of rights, like participation in political community, is ultimately a practical matter.

What is to be decided and how, are themselves part of the process of selfdetermination or dialogue between and within constituencies. Dialogue - the conversations within, across and among cultures - occurs in particular historical, political and practical contexts. But it can nevertheless be 'open' in the sense of having outcomes that are not heavily predetermined and if all parties involved are prepared to accept change. The concept of rights that operates (weakly) under forms of assimilation has required change only on the part of Indigenous people - if supposedly intended for 'their benefit'. For the rights that articulate self-determination, all parties must accept change. For nonindigenous society, structures and institutions, accommodation involves listening to and engaging with Indigenous people and social forms in a way that accepts the possibility of 'loss' of control and the fluidity that negotiation brings. That is, it involves 'respecting the human rights' of Indigenous people. 'If the demand [for forms of self-determination] far exceeds what governments and the broader community are prepared to accept as appropriate then so will be set 
the ambit for negotiation or determination of the issue' (RCIADIC, 1991: Vol. 2: 509). The assertion of Indigenous rights is the entry into such open-ended processes of accommodation; it does not resolve or order those processes. This does not mean that such processes of mutual adjustment are without institutional structure or context, providing not certainty, but some reliability of exchange and engagement. Nor does it mean that Aboriginal people just 'take the land' or continue unhindered with the levels of personal violence that have scarred their communities. Again in the words of Mick Dodson:

while Indigenous peoples have the right to retain our culture, this is not an absolute 'context-free' right, irrespective of other factors... The notion that 'universal human rights' provide a clear resolution for every situation is overly simplistic. There are different sets of rights at play and they will, at times, conflict. This debate has particular significance in Australia in relation to the recognition of customary law. No general rule provides a guide for which right has primacy. The competing considerations need to be balanced, by all peoples concerned, in respect of each site of conflict (Dodson, 1995a: 68).

There is nothing inevitable about the process of negotiation. And it is far from a meeting of equal parties. History provides good reason for ambivalence about trusting the processes of engagement, particularly, of course; for indigenous peoples. But nor might it be so easy to sidestep the challenges of living together without embedding patterns of marginalisation. An inability or a refusal to engage would not be cost-free, as interracial and intersocial conflicts around the globe, or simply the confinements of rigid and intolerant societies, scored with entrenched suffering, suggest. And 'relations of power are not the whole story. Arguments of justice, consistency of principle and moral appeal remain important (though by no means determinative) as indeed they have been throughout Australia's recent grappling with indigenous rights', while power is itself woven with questions of value (Webber, 2000: 74).

Entering conversations with Aboriginal communities and people, over health, policing, education, land, dance, music, family and so on, provides and demands the opportunity to open the door of Australia's political life in the broadest sense of the word, just as Mabo opened a space for a law that is outside, but now intertwined with, Australian common law. The slow process of gaining land rights has tentatively recognised Aboriginal people as having a 'special' place in the dynamics of Australian political life. This 'specialness' is being vigorously fought by those (such as the One Nation Party) who believe that egalitarian values, or community, demand sameness; but, if it continues, this development might rather mean more open and complex avenues of participation in political life for Australians more generally. To recognise Indigenous people as interlocutors on their own terms, in their own, various selves, also requires an acknowledgment of the history of the Australian state. That history, 
in its general sweep but also its particular, localised and diverse legacy of encounters, is a valuable shared resource for exchange. 'People draw upon [the national past] in their arguments and their claims, and as they do, they suggest what is most valuable, and what should be left behind' (Webber, 2000: 80). An apology is part of this, as could be a treaty process. An apology may be useful for the process of healing, to which many Aboriginal people refer; it would also explicitly recognise Aboriginal people as participants and recognise the fact and the character of the history to the conversation - theirs and (for what can sweepingly be called 'mainstream' Australia) ours.

Participation, or engagement, is intrinsically an open-ended ethic, with, in practice, multiple parties. This is not to say, however, that on a practical level there are no structures for situating dialogue, no mechanisms for moving forward or localised histories providing impetus and shaping pathways. Mutual accommodation is a lengthy, on-going and many-sided process that requires organs of interaction and collaboration, as well as flexibility (Webber, 2000). In the health arena, the AMS and the NACCHO were set up by Indigenous people to work with both Indigenous health needs and understandings and the health resources and systems of the wider community. Other local or national bodies may well emerge. The AMS was one of the first Indigenous institutional efforts to set out to assert effective self-determination within the context of Australian political and social systems. These bodies, with which there is already some history of negotiation, provide a place to start. ${ }^{8}$

The processes of negotiation are not purely a domestic Australian matter, as the Mabo case also reminds us. As a tenet of international law since the seventeenth century, the principle of terra nullius was part of that system which, certainly not without debate, articulated how to deal with difference within the ambit of the 'civilised' states of Christian Europe on the one hand - that is, through principles of non-interference in sovereign jurisdictions - and how to deal with the difference between these 'sovereign jurisdictions' and the 'less civilised' races or the 'lawless savages' on the other hand. Terra nullius has been intrinsic to the language and processes of colonisation and the history of the state system. It has not been a static principle. The high court decision which overturned its application in the Mabo case was, in the broadest sense, part of the on-going revolutions of the state system that are gestured to as imperialism, colonisation and the slow mutations of decolonisation. It was more directly part of the international legal and political conversation regarding indigeneity and what stand as the criteria and constitution of political community.

The majority judgment in that case drew partly on international legal norms and decisions which are now marked by decades of decolonisation. In so recognising Aborigines as a people or a political body, with a way of life and a law, this decision amended the standing of Indigenous people within common law: 'The High Court's judgement [recognising native title] . . . was, in itself, an 
act of reconciliation between two laws. It declared the common law of Australia and recognised what has always been true in the law of Indigenous Australians' (Dodson, 1993: 13). In fact the Mabo decision was a very public transaction between three laws that are not neatly distinct but evolving and historically interpenetrating: Australian common law, traditional and continuing Indigenous law and international law in the form, most importantly for this case, of the Convention on the Elimination of All Forms of Racial Discrimination, ${ }^{9}$ as well as a body of case law. Thus, in this case, the appeal to or recognition of rights that predate the establishment of the state or the colony does not depend upon a claim to universalism or to 'man in nature' or a veil of ignorance, but rather recognises the process of negotiation and the need to deal across and between actual political communities that are the starting-point of rights as participation.

The challenge to re-work the practices of citizenship that Indigenous people present to Australian political life and non-indigenous people, to the liberal norms of the state and to the complex function of those norms in the operation of the state system, again underlines the paucity of arguments which remain closed within an opposition between citizenship rights and the 'rights of man', or the particularity of the state and the universal. The 'rights of man' have to a significant extent been part of the historical articulation of a dominant set of practices and a language of the state and the citizen - a set of practices in which various categories of people have had little or no effective place. At the same time 'citizenship' is not a settled category limited to black letter law within the allegedly clear confines of state jurisdictions. It is a slowly shifting set of transactions constituted and shaped by the changing dynamics of world politics and the state system, as well as by the lives of people, intersecting constituencies and the dynamics of social institutions and orders within states.

\section{NOTES}

1 'We are still the stereotyped welfare class of people as viewed by the Australian public. Sadly, deep down we view ourselves in a similar way ... We are, with some exceptions, in every demeaning sense, largely dependent on our annual welfare handout' (Perkins, in Hunter, 1993: 264-5).

2 Different names are commonly used to refer to Aboriginal people from different regions. Names include Murri (north-eastern) and Koori (south-eastern). These are not clan or tribal names.

3 This tension between different dimensions of rights is central to a debate within the Indigenous community between those who advocate pursuit of political relationship with settler Australia through an emphasis on rights, and the rejection of that position, because of the welfare dependence with which it has become associated. This second view emphasises instead the assertion of and quest for economic self-determination, identifying economic power as key to survival.

4 As the preliminary Water Report noted: 'The consultation process with Aboriginal and Torres Strait Islander people . . . is a matter of serious concern. Much of the information 


\section{Australia}

transmitted in technical discussions is either irrelevant or meaningless to people with a different cultural or historical experience. Despite this, [Indigenous] community councils are asked to make decisions on million dollar projects. Consultants employed to advise on projects are often not aware of the wider needs of the community. There is very little real opportunity for communities to negotiate alternative options' (HREOC, 1994: 11-12).

5 At the same time Aboriginal clinics and organisations are, rather ironically, given stringent accountability mechanisms.

6 'The construction of problems to fit solutions is particularly seductive for health, where the medicalisation of social problems appeals to both political and health care delivery systems' (Hunter, 1993: 266).

7 As Sally Morgan has said: 'In the telling [of our stories] we assert the validity of our own experiences and we call the silence of two hundred years a lie. And it is important to you, the listener, because like it or not, we are a part of you. We have to find a way of living together in this counting, and that will only come when our hearts, minds and wills are set towards reconciliation' (RCIADIC, 1991: Vol. 2: 44).

8 Many Aboriginal community councils and associations work effectively as a third tier of government. '[T]hey not only have the potential to establish and deliver essential services: in the fullest form they can operate as the medium of full community selfgovernment' (Dodson, 1993: 59).

9 CERD was fully ratified and then incorporated into Australian domestic law in 1975, in the form of the Racial Discrimination Act. This Act played a key role in the judgment in Mabo. 